Journal of the

Marine Biological Association

of the United Kingdom

国圈国 CAMBRIDGE

\title{
Identifying key habitat and seasonal patterns of a critically endangered population of killer whales
}

\begin{tabular}{|c|c|}
\hline Journal: & Journal of the Marine Biological Association of the United Kingdom \\
\hline Manuscript ID: & JMBA-12-12-SI-0444.R1 \\
\hline Manuscript Type: & Special Issue Article \\
\hline Date Submitted by the Author: & 13-Jun-2013 \\
\hline Complete List of Authors: & $\begin{array}{l}\text { Esteban, Ruth; CIRCE, Conservation Information and Research on } \\
\text { Cetaceans } \\
\text { Verborgh, Philippe; CIRCE, Conservation Information and Research on } \\
\text { Cetaceans } \\
\text { Gauffier, Pauline; CIRCE, Conservation Information and Research on } \\
\text { Cetaceans } \\
\text { Giménez, Joan; GEMA, Grupo de Ecología Marina Aplicada, Estación } \\
\text { Biológica de Doñana, CSIC } \\
\text { Afan, Isabel; LAR, Laboratorio de SIG y Teledetección, Estación Biológica } \\
\text { de Doñana, CSIC } \\
\text { García, Pedro; ANSE, Asociación de Naturalistas del Sureste } \\
\text { Murcia, Jose Luis; ANSE, Asociación de Naturalistas del Sureste } \\
\text { Magalhães, Sara; Mar Ilimitado, } \\
\text { Andreu, Ezequiel; TURMARES, Turísmo Maritimo del Estrecho } \\
\text { de Stephanis, Renaud; GEMA, Grupo de Ecología Marina Aplicada, Estación } \\
\text { Biológica de Doñana, CSIC }\end{array}$ \\
\hline Keywords: & $\begin{array}{l}\text { Killer whale, Orcinus orca, distribution, spatial modelling, GAM, cetacean, } \\
\text { Strait of Gibraltar, Southern Iberian Peninsula }\end{array}$ \\
\hline Abstract: & $\begin{array}{l}\text { Killer whales have been described in the Gulf of Cadiz, southern Spain, in } \\
\text { spring and in the Strait of Gibraltar in summer. A total of } 11,276 \text { cetaceans } \\
\text { sightings coming from different sources (dedicated research surveys, whale } \\
\text { watching companies and opportunistic observations) were used to create } \\
\text { two presence-"pseudo-absence" predictive generalised additive models } \\
\text { (GAM), where presence data were defined as sightings of killer whales and } \\
\text { "pseudo-absence" data as sightings of other cetacean species. One model } \\
\text { was created using spring data when killer whales' main prey, Atlantic } \\
\text { bluefin tuna, enters the Mediterranean Sea and the other model used } \\
\text { summer data when Atlantic bluefin tuna returns to the Atlantic Ocean. Both } \\
\text { model predictions show that killer whales are highly associated with a } \\
\text { probable distribution of bluefin tuna during their migration throughout the }\end{array}$ \\
\hline
\end{tabular}




\begin{tabular}{|l|l|}
\hline $\begin{array}{l}\text { study area, constraining their distribution to the Gulf of Cadiz in spring and } \\
\text { the Strait of Gibraltar in spring and summer. Knowledge of the distribution } \\
\text { of killer whales in the study area is essential to establish conservation } \\
\text { measures for this population. } \\
\text { Abstract.doc }\end{array}$ \\
\hline
\end{tabular}

\section{SCHOLARONE \\ Manuscripts}


2 Identifying key habitat and seasonal patterns of a critically 3 endangered population of killer whales

4

5

6

7

8

\author{
Ruth Esteban ${ }^{1}$, Philippe Verborgh ${ }^{1}$, Pauline Gauffier ${ }^{1}$, Joan Giménez ${ }^{2}$, Isabel Afán ${ }^{3}$, \\ Ana Cañadas ${ }^{4}$, Pedro García ${ }^{5}$, Jose Luis Murcia ${ }^{5}$, Sara Magalhães ${ }^{6}$, Ezequiel Andreu ${ }^{7}$, \\ Renaud de Stephanis ${ }^{2}$ \\ ${ }^{1}$ CIRCE, Conservation Information and Research on Cetaceans, C/ Cabeza de \\ Manzaneda 3, Algeciras-Pelayo, 11390 Cadiz, Spain. \\ ${ }^{2}$ GEMA, Grupo de Ecología Marina Aplicada, Estación Biológica de Doñana, CSIC. C/ \\ Americo Vespucio, s/n, 41092, Isla de la Cartuja, Sevilla, Spain. \\ ${ }^{3}$ LAST, Laboratorio de SIG y Teledetección, Estación Biológica de Doñana, CSIC. C/ \\ Americo Vespucio, s/n, 41092, Isla de la Cartuja, Sevilla, Spain \\ ${ }^{4}$ Alnilam Research and Conservation, Cándamo 116, 28240 Hoyo de \\ Manzanares, Madrid, Spain. \\ ${ }^{5}$ ANSE Asociación de Naturalistas del Sureste Plaza Pintor José María Párraga, 11. \\ Bajo, 30002, Murcia. \\ ${ }^{6}$ MAR ILIMITADO Porto da Baleeira de Sagres, 8650-368 Sagres, Portugal \\ ${ }^{7}$ TURMARES (Turísmo Maritimo del Estrecho), Avd/ Alcalde Juan Nuñez 3, 11380 \\ Tarifa, Cadiz. Spain \\ Corresponding author: R. Esteban \\ E-mail: ruth@circe.info
}




\section{ABSTRACT}

27 Killer whales have been described in the Gulf of Cadiz, southern Spain, in spring and in 28 the Strait of Gibraltar in summer. A total of 11,276 cetaceans sightings coming from 29 different sources (dedicated research surveys, whale watching companies and 30 opportunistic observations) were used to create two presence-"pseudo-absence" 31 predictive generalised additive models (GAM), where presence data were defined as 32 sightings of killer whales and "pseudo-absence" data as sightings of other cetacean 33 species. One model was created using spring data when killer whales' main prey, 34 Atlantic bluefin tuna, enters the Mediterranean Sea and the other model used summer 35 data when Atlantic bluefin tuna returns to the Atlantic Ocean. Both model predictions 36 show that killer whales are highly associated with a probable distribution of bluefin 37 tuna during their migration throughout the study area, constraining their distribution to 38 the Gulf of Cadiz in spring and the Strait of Gibraltar in spring and summer. 39 Knowledge of the distribution of killer whales in the study area is essential to establish 40 conservation measures for this population.

42 Keywords: killer whale, Orcinus orca, distribution, spatial modelling, GAM, cetacean, Strait of 43 Gibraltar, Southern Iberian Peninsula 
45

46

47 Modelling species distribution is a valuable tool of biological conservation efforts,

\section{INTRODUCTION} especially predictive models of marine predators due to the logistical difficulties of monitoring their distributions at sea. For instance, managers of whale and dolphin populations can benefit from accurate model-derived predictions of cetacean habitat to mitigate anthropogenic effects, such as fisheries by-catch (Torres et al., 2003) the impacts of habitat alterations on ecosystem function (Baumgartner \& Mullin, 2001; D’Amico et al., 2003), in order to protect critical habitat (Hooker et al. 1999; Cañadas et al. 2005; Gregr \& Trites 2011) and understand the ecology of these animals (Hamazaki, 2002). By assuming that the distribution of cetaceans is non-random relative to environmental variability, predictive models of cetacean distribution typically identify the ecological relationships between the environment and species habitat selection.

Killer whales, Orcinus orca (Linnaeus, 1758) have a widespread distribution throughout the world's oceans and seas, from polar waters to the equator ( Leatherwood \& Dalheim, 1978; Heyning \& Dahlheim, 1988; Forney \& Wade, 2007). They are known to be common in many coastal areas, particularly at high latitudes, probably due to higher ocean productivity (Forney \& Wade, 2007), but they also occur in offshore and tropical waters (Leatherwood \& Dalheim, 1978; Forney \& Wade, 2007). Killer whales are known to present seasonal movement patterns, often associated with increased prey availability in the Northeast Pacific ( Braham \& Dahlheim, 1982; Baird \& Dill, 1995), North Atlantic (Sigurjónsson \& Leatherwood, 1988) and South Atlantic (Iñiguez, 2001). In the Atlantic, they are common around the northern part of the British Isles, along the Norwegian coast and throughout the eastern North Atlantic. They occasionally enter the 
70 North Sea and Skagerrak Strait (Reid et al., 2003). Killer whales are regularly seen in

71 the Strait of Gibraltar and adjacent Atlantic waters (Horozco, 1598; Aloncle, 1964a;

72 Casinos \& Vericad, 1976; Bayed \& Beaubrun, 1987; Guinet et al., 2007; de Stephanis

73 et al., 2008; Esteban, 2008; Foote et al., 2011). Conversely, killer whales are considered

74 as a rare species in the Mediterranean Sea (Casinos \& Vericad, 1976; Raga et al., 1985;

75 Bayed \& Beaubrun, 1987; Notarbartolo di Sciara, 1987; Notarbartolo di Sciara \&

76 Birkun, 2010).

77 In Southern Spain, killer whales are observed in spring in the Gulf of Cadiz ( Guinet et

78 al., 2007; García-Tiscar, 2009), when their main prey, Atlantic bluefin tuna (hereafter

79 ABFT) (Thunnus thynnus), enters the Mediterranean Sea (Cetti, 1777; Sella, 1929;

80 Rodríguez-Roda, 1964) and in summer associated with the ABFT long-line fishery of

81 the Strait of Gibraltar, (Srour, 1994; de la Serna et al., 2004) when ABFT return from

82 their spawning areas on their way back to the Atlantic Ocean (Lozano, 1958;

83 Rodríguez-Roda, 1964; Aloncle, 1964b; de Stephan et al., 2008). These killer whales

84 belong to the same population as killer whales sampled in the Canary islands, and are

85 significantly different from other populations in the northeast Atlantic (North Sea,

86 Iceland and Norway) (Foote et al., 2011). Additionally, differences in carbon and

87 nitrogen stable isotopes ratios (García-Tiscar, 2009) and parasite load (Mackenzie,

88 1999; Dwyer \& Visser, 2011) among pods from the "Strait of Gibraltar-Canary Island

89 population" suggest that it is a non-cohesive population that may not follows the same

90 resource all year round.

91 Due to their small population size, the killer whales of the Strait of Gibraltar and

92 contiguous waters have been recommended to be included in the "Critically

93 Endangered" category by ACCOBAMS-IUCN (Cañadas \& de Stephanis, 2006).

94 Likewise, the International Whaling Commission has recommended to implement a 
95 conservation plan for this subpopulation as soon as possible (IWC 2007) and since

96 2011, the Spanish Ministry of Environment considers the killer whales of the Strait of

97 Gibraltar and the Gulf of Cadiz as "Vulnerable" in the Spanish Catalogue of

98 Endangered Species. Both local (Andalusia) and Spanish authorities have recommended

99 studying the spatial distribution of the species in southern Spain, to delineate it, and the

100 boundaries to be managed for a correct implementation of the conservation plan.

101 A great effort has been done to describe the distribution of marine mammals in the

102 Alboran Sea and Strait of Gibraltar (Cañadas et al., 2005; Cañadas \& de Stephanis,

103 2006; Cañadas \& Hammond, 2006; Guinet et al., 2007; de Stephanis, et al., 2008a, b;

104 Verborgh et al., 2009; Foote et al., 2011), but little is known about the distribution of

105 killer whales in the whole study area, as only one publication describes the summer

106 distribution in the central area of the Strait of Gibraltar (de Stephanis et al 2008a), and

107 no information is available for the rest of the Alboran Sea or the Gulf of Cadiz. This

108 study aims to understand the spatial distribution of killer whales in the southern Iberian

109 Peninsula in relation to different environmental variables, both in spring and summer,

110 from data series compiled from research, whale watching vessels and opportunistic data. 


\section{Study Area}

116 The present study was carried out in the Gulf of Cadiz, Strait of Gibraltar and the 117 Alboran Sea (Figure 1). It is comprised between $0^{\circ} 30^{\prime}$ East and $9^{\circ} 30^{\prime}$ West and between $11837^{\circ} 30^{\prime}$ and $35^{\circ}$ North, and is bounded to the North by the Iberian Peninsula and to the 119 south by Africa. These areas display different bathymetric features. The Gulf of Cadiz 120 has a wide, smooth shelf and slope. In contrast, the northern shelf of the Alboran Sea is 121 very narrow, but has a very steep shelf and slope gradient. The Gulf of Cadiz, located in 122 the eastern sector of the central North Atlantic, is concave in shape, with a NW-SE 123 orientation (Malod, 1982; Roberts, 1970). The physiographic profile of the margin 124 includes a wide shelf $(30-40 \mathrm{~km})$ with a sea-floor slope of $0.2-0.32^{\circ}$, a shelf-break 125 located at a water depth of between 140 and $120 \mathrm{~m}$, and a smooth continental slope, 126 with sea-floor gradients of $1.5^{\circ}$ in the upper part and $0.5-1^{\circ}$ in the middle and lower 127 parts (Baraza et al., 1999). The Strait of Gibraltar has a length of $60 \mathrm{~km}$ (on an east-west 128 axis), and a mean width of $20 \mathrm{~km}$. The shallowest depth, less than $300 \mathrm{~m}$, is found in the main sill of Camarinal and its minimum width of around $14 \mathrm{~km}$ coincides with the 130 contraction of Tarifa narrow. The bathymetry of the Strait is characterised by a west to 131 east canyon, with shallower waters (200 to $300 \mathrm{~m})$ found on the Atlantic side and 132 deeper waters (800 to $1000 \mathrm{~m}$ ) on the Mediterranean side. On the eastern side of the 133 Strait of Gibraltar lies the Alboran Sea basin, at the western edge of the Mediterranean 134 Sea. It is arc-shaped, and characterised generally by a complex physiography related to 135 its tectonic history. The Spanish margin has a very narrow, steep shelf $(5-10 \mathrm{~km})$ up to 136 the shelf-break at 110-120 m water depth, which establishes the boundary, with a shelf 
137 gradient of $0.5-0.7^{\circ}$ and a slope of $2.3^{\circ}$ (Ercilla et al, 1992; Hernández-Molina, 1993;

138 Hernández-Molina et al., 1994).

139

140

141

142 Sightings from cetaceans collected between 2002 and 2012 in waters of the southern

143 Iberian Peninsula were compiled. The datasets were separated in two data sets as killer

144 whales have been described in different areas during different seasons: shallow waters

145 in the Gulf of Cadiz in spring (April-June) (Guinet et al., 2007), and in the central

146 waters of the Strait of Gibraltar in summer (July-September) (de Stephanis et al.,

147 2008a). We have also based this separation on the migration pattern of their main prey,

148 bluefin tuna (Cetti, 1777; Sella, 1929; Rodríguez-Roda, 1964). Insufficient data were

149 available to make robust spatial models for the rest of the year. A total of 11,276

150 records of cetaceans were available for this analysis coming from: (1) random transect

151 sightings from a research boat performed by the NGO ANSE (Asociación de

152 Naturalistas del Sureste) in the Murcia region; (2) sightings collected by Alnitak since

153 2002, a research NGO which performed random transect throughout the Alboran Sea

154 (Cañadas et al., 2005); (3) sightings collected by Alnilam since 2010, a research

155 company which performed random transect throughout the Alboran Sea; (4) sightings of

156 CIRCE (Conservation, Information and Research on Cetaceans) since 2002, a research

157 NGO that made random and line transect throughout the Strait of Gibraltar and Gulf of

158 Cadiz (de Stephanis et al., 2008); (5) sightings of TURMARES (Turismo Marítimo del

159 Estrecho) since 2003, a whale watching company based in the Strait of Gibraltar; (6)

160 sightings from Mar Ilimitado (Tourism and Research) since 2005, a whale watching and

161 research company and based in southern Portugal; (7) sightings from Consejería de

162 Medio Ambiente de la Junta de Andalucía, a governmental institution of the local 
163 council of Andalucía since 2005, that performs random and line transect by boat and

164 airplane throughout the entire Andalusian region, (8) sightings collected by the EBD-

165 CSIC (Estación Biológica de Doñana - Consejo Superior de Investigaciones Científicas)

166 since 2011, from a small research boat doing line transects in the Gulf of Cádiz and (9)

167 opportunistic data.

168

169

\section{Environmental explicative models}

170

171 Habitat preferences of killer whales within the study area were investigated. The

172 relationships between the spatial occurrence of the whales, and environmental variables

173 were assessed using generalised additive modelling (GAM) techniques (Hastie \&

174 Tibshirani, 1990). The open-source statistical programming language $\mathrm{R}$ version 2.6.2

175 (http://cran.r-project.org/), and the MGCV library within R were used (Wood, 2001).

176 Given that data were coming from different sources, types of effort are difficult to

177 compare, and therefore a model based on presence and "pseudo-absence" was used. A

178 GAM with a tweedie distribution and logit link function was used. The parameter $\mathrm{p}$

179 chosen for the Tweedie distribution, through inspection of GCV (Generalised Cross

180 Validation score, an approximation to AIC, Wood 2000), was 1.1, very close to a

181 Poisson distribution but with some over-dispersion. The model used a gamma=1.4, as

182 recommended by Wood (2006), to prevent overfitting.

183 All the cetaceans' sightings were used as "sampling stations". The presence dataset

184 included sightings of killer whales obtained by the different platforms. We used all the

185 other cetacean species in the study area as "pseudo-absences". In these locations, we

186 assumed that an observer was effectively searching whales as other species were

187 sighted, however killer whales were not detected. The general structure of the model 188 was:

$E\left(p_{i}\right)=\exp \left[\theta_{0}+\sum_{k} f_{k}\left(z_{i k}\right)\right]$. 
190 Where $p_{i}$ is the probability to find killer whales, in the $i^{\text {th }}$ sampling station, $\theta_{0}$ is the

191 intercept, $f_{k}$ are smoothed functions of the explanatory covariates, and $z_{i k}$ is the value of

192 the $k^{\text {th }}$ explanatory covariate in the $i^{\text {th }}$ sampling station. The environmental variables

193 used in this study were depth, obtained from ETOPO2 (Amante \& Eakins, 2009), its

194 derivate slope and aspect (obtained with the R library SDMtools (VanDerWal et al.,

195 2010), sea surface temperature (SST) and chlorophyll a concentration (Chla) obtained

196 from satellite images of MODIS (Carder et al., 2003). Spatial (geographic) covariates,

197 i.e. latitude and longitude, were also used as potential proxies for other unavailable or

198 unknown features affecting whales' distribution. Model selection was done using three

199 diagnostic indicators: (a) the GCV (Generalised Cross Validation score, an

200 approximation to AIC); (b) the percentage of deviance explained; and (c) the probability

201 that each variable was included in the model by chance. The decision to include/drop a

202 term from the model was adopted following the criteria proposed by Wood (2001).

203

204

205

206

207

208

209

210

211

212

213

214

215

\section{Environmental predictive models}

The best GAM models were used to generate predicted probability values of presence and pseudo-absence on a grid of $2 \times 2 \mathrm{~km}$ in the study area, which were plotted using ArcMap 10.0. In order to obtain the $95 \%$ confidence interval of the predictions, 1000 bootstraps with replacement were run for each model, and a prediction was obtained for each bootstrap iteration. The $95 \%$ confidence intervals were obtained from the bootstrap process of the models predictions of killer whales in the study area and were also plotted in to assess the precision of the predictions in every point of the study area.

\section{RESULTS}


216 Between 2002 and 2012, 322 sightings of killer whales and 10,952 sightings of other

217 cetaceans were recorded in the study area. We created two models for the presence of

218 killer whales in the area (spring and summer). A total of 44 sightings of killer whales

219 and 3746 of other cetaceans were recorded in spring. During this season the best model

220 included two covariates (see Table 1): depth and longitude, both highly significant, and

221 explaining $50.4 \%$ of the deviance. Killer whales presence was expected between 0 and

222950 meters depth showing a linear increasing pattern towards shallower waters and

223 between $8.5^{\circ}$ and $4^{\circ}$ longitude West (see Figure 2) with an equally higher presence for

224 this longitude range and a decrease for the rest of the area, with a higher coefficient of

225 variation (see Figure 4).

226 In summer 278 sightings of killer whales and 7206 of other cetaceans were recorded.

227 The best model included three covariates: depth, longitude and sea surface temperature, 228 all of them significant and explaining in total $49.60 \%$ of the deviance. Presence 229 probability was higher at 0-950 meters depth, between $8.5^{\circ}$ and $4^{\circ}$ longitude West and at $230 \quad 19-24^{\circ} \mathrm{C}$ sea surface temperature (see Figure 3 ).

231 The spring model prediction map shows two important areas for the presence of killer

232 whales, one in the eastern part of the Gulf of Cadiz in shallow Spanish and Moroccan

233 waters and another one in the South of Portugal (Figure 4). While the variance is very

234 low for the Gulf of Cadiz, it is high in South of Portugal (Figure 4).

235 The summer model prediction map shows a high presence only in the western-central 236 part of the Strait of Gibraltar (Figure 5), with little variance in the prediction (Figure 5). 
240 This study highlights the importance of collaborative datasets to understand the

241 distribution of animals with low encounter rates. The kind of datasets we have used are

242 statistically difficult to deal with, due to the differences in surveying conditions, but

243 these data are of great importance to understand which environmental variables are

244 responsible for the spatial distribution of this species. Here we have solved the

245 heterogeneity of effort from different datasets, by using other cetacean species presence

246 as a proxy for killer whales absence. Recent studies have highlighted several methods

247 for selection of pseudo-absence including: random (Stockwell, 1999); random with

248 geographic-weighted exclusion (Hirzel, Helfer, \& Metral, 2001), random with

249 environmentally weighted exclusion (Zaniewski et al., 2002) and locations that have

250 been visited (i.e., occurrences for other species, like in our case) but where the target

251 species was not recorded (Elith \& Leathwick, 2007). The benefits of each technique

252 have been discussed previously (Lütolf et al., 2006; Phillips \& Dudík, 2008), and are

253 out of the scope of this study. Although the chosen approach is not ideal, in our opinion

254 it is suitable due to the high amount of sightings of other cetacean species in the study

255 area, and the non-availability of homogenous effort.

256 We have demonstrated clear and predictable influences of environmental and

257 geographical factors on the distribution of killer whales in this region. The results

258 support previous studies showing that killer whales are encountered in shallow waters

259 of the south-western part of the Strait of Gibraltar in summer (de Stephanis et al., 2008).

260 The distribution pattern of the species seems to be closely linked to the bathymetric

261 structure within the area. Previous studies have shown that water depth can be a

262 significant factor in determining the distribution of marine top predators e.g. (Selzer \& 
263 Payne, 1988; de Stephanis et al., 2008; Schneider, 2008). These authors suggested that

264 the importance of water depth was related to prey availability.

265 ABFT live in pelagic ecosystems of the entire North Atlantic and its adjacent seas, 266 primarily the Mediterranean Sea (Fromentin \& Powers, 2005). Some tuna born in the

267 Mediterranean Sea, leave and undertake trophic migrations within the eastern Atlantic

268 Ocean up to age 4 or 5 , at which point they reach sexual maturity and return to the 269 Mediterranean Sea to spawn in spring (Aloncle, 1964b; Cort, 1990; Dicenta \& 270 Piccinetti, 1978; Mather, Mason, \& Jones, 1995). Then, ABFT return to the Atlantic 271 Ocean in summer crossing the Strait of Gibraltar in a trophic migration (Sella, 1929;

272 Rodríguez-Roda, 1964). The different predicted spatial distributions of killer whales in 273 spring and summer match the spawning and trophic migrations of ABFT through the 274 study area.

275 The spring model predicts killer whales presence in shallow waters close to the west 276 coast of the study area, where they would be capable of hunting schools of ABFT 277 entering the Mediterranean, using the endurance-exhaustion hunting technique 278 described in the Gulf of Cadiz ( $<100 \mathrm{~m}$ depth) by Guinet et al. (2007). Killer whales are 279 known to dive to depths no more than 300 m (Bowers \& Henderson, 1972). Hunting in 280 shallow waters can prevent ABFT from taking refuge at depths (Guinet et al. 2007).

281 In addition to depth and longitude, temperature had a significant influence on the 282 presence probability of killer whales during summer, restricting their distribution area to 283 the Strait of Gibraltar. Quílez-Badia et al. (2012) showed that ABFT were crossing the 284 Strait between 19 and $24^{\circ} \mathrm{C}$ while swimming to the Atlantic Ocean, which matches the 285 temperature range predicting the presence of killer whales in the Strait of Gibraltar in 286 summer in this study. Deep dives have been reported through the use of tags on ABFT 287 while they are crossing the Strait of Gibraltar (Wilson \& Block, 2009), suggesting that 
288 (a) they may forage on squid and fish inhabiting deep Mediterranean outflow waters, or

289 (b) maybe these dives were related to predator avoidance by the killer whales, or (c)

290 thermoregulation and energetic saving associated with avoiding ocean currents. Since

291 1995, Spanish and Moroccan fisheries have been established and developed near sea

292 mounts in the Strait of Gibraltar during the western tuna migration ( Srour, 1994; de la

293 Serna et al., 2004). Killer whales have been observed among fishing boats at least since

2941999 in the central part of the Strait (de Stephanis et al., 2008), (a) depredating tuna

295 from the long-lines or (b) actively chasing tuna in the area, in these shallower waters

296 where ABFT are not able to avoid them by performing deep dives. The presence of

297 ABFT long-line fisheries, the shallow waters of the Strait, as well as the bottleneck that

298 represents the Strait of Gibraltar for the migration of the ABFT would explain the high

299 predictability of the species in the area both in summer and spring.

300 In the Alboran Sea a large effort has been made for the study of cetaceans, but only four

301 sightings of killer whales have been recorded in the area in 10 years (Figure 1), and

302 none of the selected models have identified any important area for killer whales in that

303 area in this study (Figures 4 and 5). The Alboran Sea is characterised by a narrow, steep

304 shelf (5-10 km) (Ercilla et al., 1992; Hernández-Molina, 1993; Hernández-Molina et

$305 a l ., 1994)$ compared to the wide shelf $(30-40 \mathrm{~km})$ of the Gulf of Cadiz (Baraza et al.,

306 1999). This difference could be crucial for the presence of killer whales in the area, as

307 they seem to prefer hunting in shallow areas (Guinet et al., 2007). Therefore, it seems

308 better for the killer whales to wait for ABFT near the shallow sea mounts of the Strait of

309 Gibraltar and adjacent waters. In southern Portugal (Algarve), there are few sightings of

310 killer whales (Figure 1), but the spring model predicts an important area near Faro

311 (Figure 4). This area used to be one of the main places for Portuguese tuna trap nets

312 (Ravier \& Fromentin, 2001), therefore it could be a suitable area for killer whales 
313 endurance-exhaustion hunting (Guinet et al., 2007). Little effort was available in

314 Algarve, and the model prediction shows a great variance in the area (Figure 4), that

315 could be due to the low availability to "pseudo-absences" in the models (Figure 1).

316 Therefore, this area should be further surveyed to improve the spring model prediction.

317 No cetacean survey has been made in Moroccan waters; however the spring model has

318 identified the north Atlantic coast of Morocco as an important area. Further studies

319 should focus on refining habitat predictions and examining relationships between killer

320 whale distributions and environmental correlates over the years and in areas not so well

321 studied as Moroccan and Portuguese coasts and offshore waters of the Southern Iberian

322 Peninsula. Scarce sightings (both of killer whales and other species) were recorded in

323 autumn and winter, which did not allow modelling their presence during these periods

324 of the year.

325 Conservation of the eastern Atlantic stock of killer whales' prey is essential for the

326 future of both endangered predator and prey in the area, as ABFT has been overfished

327 (Collette et al., 2012) and Iberian killer whales have a highly specialised diet (García-

328 Tiscar, 2009). The fecundity of another population of killer whales in the eastern Pacific

329 Ocean has been strongly related to the abundance of their prey, the Chinook salmon,

330 where a decrease in salmon populations caused senescence in the whales and affected

331 their fecundity rates (Ward et al., 2009). For that reason, any decrease in the abundance

332 of ABFT could set the Iberian population of killer whales at greater risk. Therefore,

333 important areas for southern Iberian killer whales require adequate protection, such as

334 the creation of an exclusion zone where activities that may disrupt their hunting

335 technique would be prohibited in spring in the eastern areas of the Gulf of Cadiz (both

336 in Spain and Morocco), such as whale watching, military exercises or sport fishing. The

337 conservation of this killer whale population distributed across national borders will only 
338 be achieved through collaboration and coordination between the neighbouring countries

339 Spain, Portugal and Morocco and the implementation of a joint action plan to protect

340 their habitat.

341

342

ACKNOWLEDGEMENTS

343

344 We would like to specially thank Alnitak for supplying their sighting data-base. Thanks

345 are due to the Consejería de Agricultura, Pesca y Medio Ambiente of the Junta de

346 Andalucía and the Agencia de Medio Ambiente y Agua of the Junta de Andalucía,

347 especially to Manuel Fernández Casado, Diego Moreno, Agustin Barrajón, Maria del

348 Carmen Arroyo, Julio de la Rosa y Jose Miguel Remón, Eduardo Fernández Tabales

349 and María Soledad Vivas. Thanks to Rebecca Bringley, Teo Todorov, Javier Elorriaga,

350 Rafael García, José María Carceles and Clive Finlayson for supplying killer whale

351 sightings. João Nuno Gonçalves, Bruno Claro, CIRCE volunteers and research

352 assistants helped in the field work of CIRCE and the EBD-CSIC. This work was funded

353 by the Loro Parque Foundation, CEPSA, Ministerio de Medio Ambiente, Fundación

354 Biodiversidad, Life Indemares (LIFE 07 NAT.E.000732) and LIFE “Conservación de

355 Cetáceos y tortugas de Murcia y Andalucía" (LIFE02NAT/E/8610), the "Plan Nacional

$356 \mathrm{I}+\mathrm{D}+\mathrm{I}$ " of the Spanish "Ministerio de Economía y Competitividad". De Stephanis was

357 supported by the "Ministerio de Economía y Competitividad" through the

358 "Subprograma Juan de la Cierva". Thanks are also due to the IFAW for providing the

359 software Logger 2000.

360 
362

363

364

365

366

367

368

369

370

371

372

373

374

375

376

377

378

379

380

381

382

383

384

385

386

387

388

389

390

391

392

393

394

395

396

397

Aloncle H. (1964a) Premières observations sur les petits cétacés des côtes marocaines. Bulletin d l'Institut des Pêches Maritimes du Maroc, 12, 21-42.

Aloncle H. (1964b) Note sur le thon rouge de la Baie Ibéro-Marocaine. Bulletin de l'Institut des pêches maritimes du Maroc, 12, 43-59.

Amante C. and Eakins B. (2009) ETOPO1 1 Arc-minute global relief model: procedures, data sources and analysis, Data Sources and Analysis. NOAA Technical Memorandum NESDIS NGDC-24, 19 pp, March 2009.

Báez J., Camiñas J. and Torreblanca D. (2007) Análisis de la distribución espacial de aves y mamíferos marinos en el Golfo de Cádiz (Sudoeste de la Península Ibérica) durante el periodo de primavera. Boletín de la Real Sociedad Española de Historia Natural. Seccion Biológica, 102, (1-4) 93-97.

Baird R. W. and Dill L. M. (1995) Occurrence and behaviour of transient killer whales: seasonal and pod-specific variability, foraging behaviour, and prey handling. Canadian Journal of Zoology Fisheries and Aquatic Sciences, 73, (7) 1300-1311.

Baraza J., Ercilla G. and H. Nelson C. (1999) Potential geologic hazards on the eastern Gulf of Cadiz slope (SW Spain). Marine Geology, 155, (1-2) 191-215.

Baumgartner M. and Mullin K. (2001) Cetacean habitats in the northern Gulf of Mexico.

Fisheries Bulletin, 99, 219-239.

Bayed A. and Beaubrun P. (1987) Les mammifères marins du Maroc: inventaire préliminaire. Mammalia, 51, (3) 437-446.

Bowers C. A. and Henderson R. S. (1972) Project Deep Ops: Deep Object Recovery with Pilot and Killer Whales. San Diego, CA.

Braham H. W. and Dahlheim M. E. (1982) Killer whales in Alaska documented in the Platforms of Opportunity Program. Report of the International Whaling Commission.

Carder K., Chen F., Lee Z., Hawes S. and Cannizzaro J. (2003) MODIS Ocean Science Team Algorithm Theoretical Basis Document, ATBD-MOD-19, Ver. 5.0.

Casinos A. and Vericad J. R. (1976) The cetaceans of the Spanish coasts: a survey. Mammalia, 40, (2) 267-290.

Cañadas A. and de Stephanis R. (2006) Killer whale, or Orca Orcinus orca (Strait of Gibraltar subpopulation). In: The status and distribution of cetaceans in the Black Sea and Mediterranean Sea, (Ed. by R. R. Reeves \& G. Notarbartolo di Sciara), pp. 34-38. IUCN, Centre for Mediterranean Cooperation, Malaga,Spain.

Cañadas A. and Hammond P. (2006) Model-based abundance estimates for bottlenose dolphins off southern Spain: implications for conservation and management. Journal of Cetacean Research and Management, 8, (1) 13-27. 
Cañadas A. and Hammond P. (2008) Abundance and habitat preferences of the short-beaked common dolphin Delphinus delphis in the southwestern Mediterranean: implications for conservation. Endangered Species Research, 4, 309-331.

401

402

403

404

405

406

407

408

409

410

411

412

413

414

415

416

417

418

419

420

421

422

423

424

425

426

427

428

429

430

431

432

433

434

435

436

437

Cañadas A., Sagarminaga R., de Stephanis R., Urquiola E. and Hammond P. S. (2005) Habitat preference modelling as a conservation tool: proposals for marine protected areas for cetaceans in southern Spanish waters. Aquatic Conservation: Marine and Freshwater Ecosystems, 15, (5) 495-521.

Cetti F. (1777) Storia naturale della Sardegna. Sassari, Piattoli.

Collette B., Amotin A. F., Boustanu A., Carpenter K. E., De Oliveira Leite Jr. N., Di Natale A., Die D., Fox W., Fredou F. L., Graves J., Viera Hazin F. H., Hinton M., Juan Jorda M., Schratwieser J., Texeira Lessa R. P., Pires Ferreira Travassos P. E. and Uozumi Y. (2012) Thunnus thynnus. In: IUCN Red List of Theatened Species. Version 2012.2,

Cort J. (1990) Biología y pesca del atún rojo,“ Thunnus thynnus”(L.), del mar Cantábrico (Tesis doctoral). Publicaciones Especiales. Instituto Español de Ocenografia, 4, 272.

D’Amico A., Bergamasco A., Zanasca P., Carniel S., Nacini E., Portunato N., Teloni V., Mori C. and Barbanti R. (2003) Qualitative correlation of marine mammals with physical and biological parameters in the ligurian sea. IEEE Journal of Oceanic Engineering, 28, (1) 29-43.

de la Serna J. D. la, Alot E., Majuelos E. and Rioja P. (2004) La migración trófica post reproductiva del atún rojo (Thunnus thynnus) a través del estrecho de Gibraltar. Collect. Vol. Sci. Pap. ICCAT, 56, (3) 1196-1209.

de Stephanis R., Cornulier T., Verborgh P., Salazar Sierra J., Pérez Gimeno N. and Guinet C. (2008a) Summer spatial distribution of cetaceans in the Strait of Gibraltar in relation to the oceanographic context. Marine Ecology Progress Series, 353, 275-288.

de Stephanis R., García-Tiscar S., Verborgh P., Esteban Pavo R., Pérez S., MinvielleSebastia L. and Guinet C. (2008b) Diet of the social groups of long-finned pilot whales (Globicephala melas) in the Strait of Gibraltar. Marine Biology, 154, 603-612.

de Stephanis R., Verborgh P., Pérez S., Esteban R., Minvielle-Sebastia L. and Guinet C. (2008c) Long-term social structure of long-finned pilot whales (Globicephala melas) in the Strait of Gibraltar. Acta ethologica, 11, 81-94.

De Stephanis R., Giménez J., Carpinelli E., Guitierrez-Expósito C. and Cañadas A. (in press). As main meal for Sperm whales: plastic deris.Marine Pollution Bulletin. Marine Pollution Bulletin,

Dicenta A. and Piccinetti C. (1978) Desove del atun ( Thunnus thynnus) en el Mediterráneo occidental y evaluacion directa del stock de reproductores, basado en la abundancia de sus larvas. Col. Vol. Sci. Pap. ICCAT, 7, (2) 389-395.

Dwyer S. and Visser I. (2011) Cookie cutter shark (Isistius sp.) bites on cetaceans, with particular reference to killer whales (orca)(Orcinus orca). Aquatic Mammals, 37, (2) 11-138.

Elith J. and Leathwick J. (2007) Predicting species distributions from museum and herbarium records using multiresponse models fitted with multivariate adaptive regression splines.

Diversity and Distributions, 13, (3) 265-275. 
438

439

440

441

442

443

444

445

446

447

448

449

450

451

452

453

454

455

456

457

458

459

460

461

462

463

464

465

466

467

468

469

470

471

472

473

474

475

476

Ercilla G., Alonso B. and Baraza J. (1992) Sedimentary evolution of the northwestern Alboran Sea during the Quaternary. Geo-Marine Letters, 12, (2-3) 144-149.

Esteban R. (2008) Abundancia, Estructura social y Parámetros demográficos de la orca (Orcinus orca) en el Estrecho de Gibraltar. Master Thesis. Universidad de Cádiz, Spain.

Foote A. D., Newton J., Piertney S. B., Willerslev E. and Gilbert M. T. P. (2009) Ecological, morphological and genetic divergence of sympatric North Atlantic killer whale populations. Molecular Ecology, 18, 5207-5217.

Foote A., Vilstrup J., de Stephanis R., Verborgh P., Nielsen S. C. A., Deaville R., Kleivane L., Martín V., Miller P. J. O., Øien N., Pérez-Gil M., Pasmussen M., Reid R. J., Robertson K. M., Rogan E., Similä T., Tejedor M. L., Vester H., Víkingsson G. A., Willerslev E., Gilbert M. T. P. and Piertney S. B. (2011) Genetic differentiation among North Atlantic killer whale populations. Molecular Ecology, 20, 629-641.

Forney K. A. and Wade P. (2007) Worldwide distribution and abundance of killer whales. In: Whales, whaling and ocean ecosystems, pp. 145-162.

Fromentin J.M. and Powers J. E. (2005) Atlantic bluefin tuna: population dynamics, ecology, fisheries and management. Fish and Fisheries, 6, (4) 281-306.

García-Tiscar S. (2009) Interacciones entre delfines mulares y orcas con pesqeuerías en el Mar de Alborán y Estrecho de Gibraltar. PhD Thesis. Universidad Autónoma de Madrid, Spain.

Guinet C., Domenici P., de Stephanis R., Barrett-Lennard L., Ford J. K. B. and Verborgh P. (2007) Killer whale predation on bluefin tuna: exploring the hypothesis of the enduranceexhaustion. Marine Ecology Progress Series, 347, 111-119.

Hamazaki T. (2002) Spatiotemporal prediction models of cetacean habitats in the mid-western North Atlantic ocean (from Cape Hatteras, North Carolina, USA to Nova Scotia, Canada). Marine Mammal Science, 18, 920-939.

Hastie T. and Tibshirani R. (1990) Generalized additive models. Monographs on Statistics and Applied Probability, 43,

Hernández-Molina F. J. (1993) Dinámica sedimentaria y evolución durante el Pleistoceno Terminal-Holoceno del margen noroccidental del Mar de Alboran. Modelo de estratigrafia secuencial de muy alta resolución en plataformas continentales. Master Thesis. Universidad de Granada, Spain.

Hernández-Molina F., Somoza L., Rey J. and Pomar L. (1994) Late Pleistocene-Holocene sediments on the Spanish continental shelves: Model for very high resolution sequence stratigraphy. Marine Geology, 120, (3-4) 129-174.

Heyning J. E. and Dahlheim M. E. (1988) Orcinus orca. Mammalian Species, 304, 1-9.

Hirzel A. H., Helfer V. and Metral F. (2001) Assessing habitat-suitability models with a virtual species. Ecological Modelling, 145, (2-3) 111-121.

Hooker S. K., Whitehead H. and Gowans S. (1999) Marine Protected Area Design and the Spatial and Temporal Distribution of Cetaceans in a Submarine Canyon. Conservation Biology, 13, (3) 592-602. 
477 Horozco A. (1598) Historia de la ciudad de Cádiz. 2nd edition. El Excmo. Ayuntamiento de 478 esta M.N.. M. L. y M. H. Ciudad.

479 Iñiguez M. A. (2001) Seasonal distribution of killer whales (Orcinus orca) in Northern 480 Patagonia, Argentina. Aquatic Mammals, 27, (2) 154-161.

481 Leatherwood J. S. and Dalheim M. E. (1978) Worldwide Distribution of Pilot Whales and 482 Killer Whales. Naval Ocean Systems Center Technical Report 443, 1-39.

483 Lozano F. (1958) Los escómbridos de las aguas españolas y marroquíes y su pesca. Trab. Inst. 484 Esp. Ocean, 25, 254.

485 Lütolf M., Kienast F. and Guisan A. (2006) The ghost of past species occurrence: improving 486 species distribution models for presence-only data. Journal of Applied Ecology, 43, (4) 802-

487815.

Mackenzie K. (1999) Parasites as biological tags in population studies of marine organisms. Parasitology, 124, S153-S163.

Malod J.A. (1982) Comparaison de l'évolution des marges continentales au Nord et au Sud de la Péninsule Ibérique. PhD Thesis. Université Curie, Paris, France.

492 Mather F., Mason J. and Jones A. (1995) Historical document: life history and fisheries of 493 Atlantic bluefin tuna. NOAA Technical Memorandum NMFS-SEFSC-370, 163pp.

494 Notarbartolo di Sciara G. (1987) Killer whale, Orcinus orca, in the Mediterranean Sea. 495 Marine Mammal Science, 3, (4) 356-360.

496 Notarbartolo di Sciara G. and Birkun A. J. (2010) Conserving whales, dolphins and porpoises in the Mediterranean and Black Seas. ACCOBAMS status report

Phillips S. J. and Dudík M. (2008) Modeling of species distributions with Maxent: new extensions and a comprehensive evaluation. Ecography, 31, (2) 161-175.

500 Quílez-Badia G., Cermeño P. and Tudela S. (2012) Movements of Bluefin tuna revealed by 501 electronic tagging in the Mediterranean sea and in Atlantic waters of morocco in 2011. ICCAT 502 SCRS/2012/123.

503 Raga J. A., Raduán A. and Blanco C. (1985) Contribución al estudio de la distribución de 504 cetàceos en el Mediterráneo y Atlantico Ibérico. Miscelánia Zoológica, 9, 361-366.

505 Ravier C. and Fromentin J.-M. (2001) Long-term fluctuations in the eastern Atlantic and 506 Mediterranean bluefin tuna population. ICES Journal of Marine Science, 58, (6) 1299-1317.

507 Reid J., Evans P. G. H. and Northridge S. P. (2003) Atlas of cetacean distribution in north508 west European waters. Joint Nature Conservation Committee (JNCC), Peterborough, 82 pp.

509 Roberts D. G. (1970) The Rif-Betic orogen in the Gulf of Cadiz. Marine Geology, 9, (5) M31510 M37.

511 Rodríguez-Roda J. (1964) Talla, peso y edad de los atunes, Thunnus thynnus (L.), capturados 512 por la almadraba de Barbate (costa sudatlántica de España) en 1963 y comparación. Inv. Pesq, 513 26, 3-48. 
514 Schneider D. C. (2008) Habitat selection by marine birds in relation to water depth. Ibis, 139, 515 (1) $175-178$.

516 Sella M. (1929) Migrazioni e habitat del tonno (Thunnus thynnus L) studiati col metodo degli ami, con osservazioni su l'accrescimento, sul regime delle tonnare ecc.

Selzer L. A. and Payne P. M. (1988) The dsitribution of White-sided (Lagenorhynchus acutus) and common dolphins (Delphinus delphis) VS. environmental features of the continental shelf of the Norheastern United States. Marine Mammal Science, 4, (2) 141-153.

521

522

523

524

525

526

527

528

529

530

531

532

533

534

535

536

537

538

539

540

541

542

543

544

545

546

547

548

549

550

Sigurjónsson J. and Leatherwood S. (1988) The Icelandic live-capture fishery for killer whales, 1976-1988. Rit. Fiskideildar, 11, (307-316).

Srour A. (1994) Développment de la nouvelle pêcherie artisanale au thon rouge dans la région de Ksar sghir. Note d'information ISPM, 26, 10-11.

Stockwell D. (1999) The GARP modelling system: problems and solutions to automated spatial prediction. International Journal of Geographical Information Science, 13, (2) 143-158.

Torres L. G., Rosel P. E., D'Agrosa C., and Read A. J. (2003) Improving management of overlapping bottlenose dolphin ecotypes through spatial analysis and genetics. Marine Mammal Science, 19, (3) 502-514.

VanDerWal J., Shoo L. and Januchowski S. (2010) SDMTools: Species Distribution Modelling Tools: tools for processing data associated with species distribution modelling exercises. R package version 1 ,

Verborgh P., de Stephanis R., Pérez S., Yaget Y., Barbraud C. and Guinet C. (2009) Survival rate, abundance, and residency of long-finned pilot whales in the Strait of Gibraltar. Marine Mammal Science, 25, (3) 523-536.

Ward E. J., Holmes E. E. and Balcomb K. C. (2009) Quantifying the effects of prey abundance on killer whale reproduction. Journal of Applied Ecology, 46, (3) 632-640.

Wilson S. and Block B. (2009) Habitat use in Atlantic bluefin tuna Thunnus thynnus inferred from diving behavior. Endangered Species Research, 10, 355-367.

Wood S. (2000) Modelling and smoothing parameter estimation with multiple quadratic penalties. Statistical Society: Series B, 62 (2): 413-428.

Wood S. (2001) mgcv: GAMs and generalized ridge regression for R. R news, 1, (2) 20-25.

Wood S. (2006) On confidence intervals for generalized additive models based on penalized regression splines. Australian \& New Zealand Journal of Statistics, 48(4):445-464.

Zaniewski A. E., Lehmann A., and Overton J. M. (2002) Predicting species spatial distributions using presence-only data: a case study of native New Zealand ferns. Ecological Modelling, 157, (2-3) 261-280.

\section{FIGURES LEGENDS}


551 Fig. 1. Cetacean sighting distribution in the study area. In red killer whales sightings and in grey other cetacean sightings. (A) sightings in spring in the southern Iberian Peninsula; (B) sighting in spring in the Strait of Gibraltar; (C) sightings in summer in the southern Iberian Peninsula and (D) sightings in summer in the Strait of Gibraltar.

Fig.2. Smoothed functions for the selected predictive covariates in the model of probability of presence of killer whales in the study area in spring. Continuous line represents the point estimate and grey areas represent \pm 1 se. The small ticks on the $X$ axis represent the samples. (A) Bathymetry and (B) Longitude.

Fig. 3. Smoothed functions for the selected predictive covariates in the model of probability of presence of killer whales in the study area in summer. Continuous line represents the point estimate and grey areas represent \pm 1 se. The small ticks on the $\mathrm{X}$ axis represent the samples. (A) Bathymetry; (B) Longitude and (C) Sea Surface Temperature.

Fig. 4. Predicted density surface map of killer whales in the area from spatial modelling in spring by bootstraps. (A) the inferior $95 \%$ C.I. of the predicted model at southern Iberian Peninsula; (B) the inferior 95\% C.I. of the predicted model in the Strait of Gibraltar; (C) best predicted model at southern Iberian Peninsula, (D) best predicted model in the Strait of Gibraltar; (E) the superior 95\% C.I. of the predicted model at southern Iberian Peninsula and (F) the superior 95\% C.I. of the predicted model in the Strait of Gibraltar.

Fig. 5. Predicted density surface map of killer whales in the area from spatial modelling in summer by bootstraps. (A) the inferior 95\% C.I. of the predicted model at southern Iberian Peninsula; (B) the inferior 95\% C.I. of the predicted model in the Strait of Gibraltar; (C) best predicted model at southern Iberian Peninsula, (D) best predicted model in the Strait of Gibraltar; (E) the superior 95\% C.I. of the predicted model at southern Iberian Peninsula and (F) the superior 95\% C.I. of the predicted model in the Strait of Gibraltar.

\section{TABLE LEGENDS}

577 Table 1: Detection-function model fits with GCV(Generalised Cross Validation score) $\Delta$ GCV between models, AIC (Akaike Information Criterion) and $\triangle$ AIC between models, during the spring period. Only covariates showing significant relationship are shown

Table 2: Detection-function model fits with GCV(Generalised Cross Validation score) $\Delta$ GCV between models, AIC (Akaike Information Criterion) and $\triangle \mathrm{AIC}$ between models and the deviation explained for each model, during the summer period. Only covariates showing significant relationship are shown 
590 FIGURES and TABLES

591

592

FIGURES: 


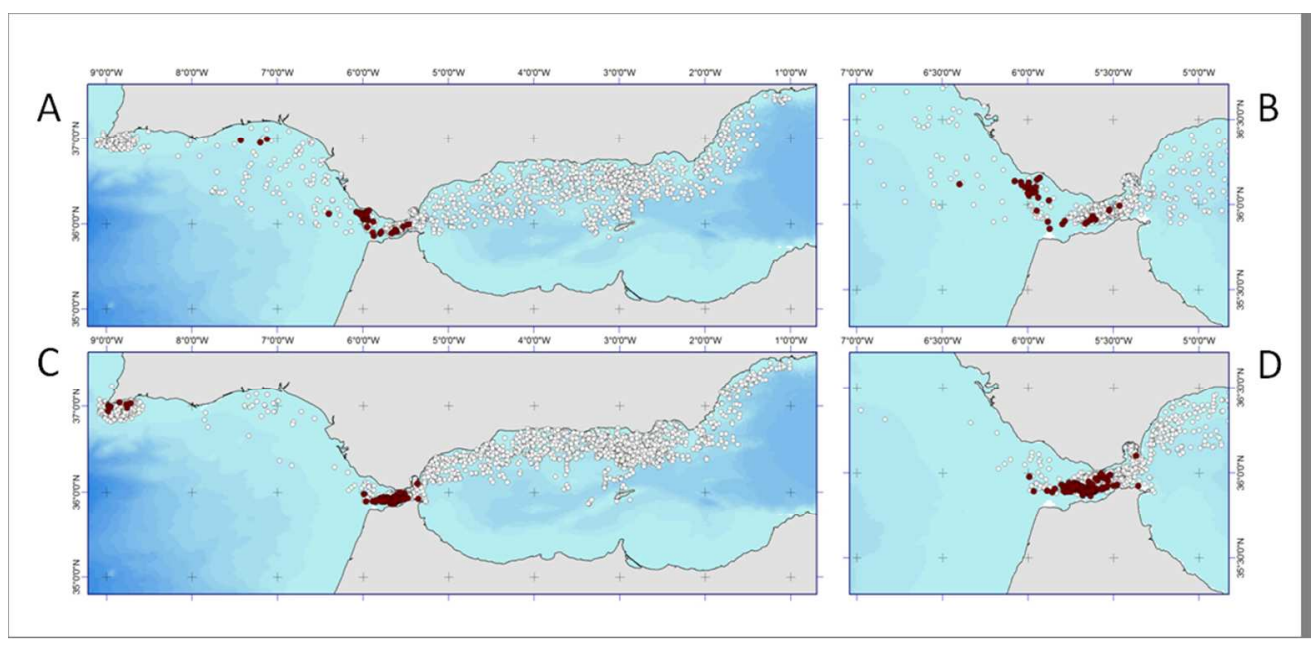

Fig. 1. Cetacean sighting distribution in the study area. In red killer whales sightings and in grey other cetacean sightings. (A) sightings in spring in the southern Iberian Peninsula; (B) sighting in spring in the Strait of Gibraltar; (C) sightings in summer in the southern Iberian Peninsula and (D) sightings in summer in the Strait of Gibraltar. 


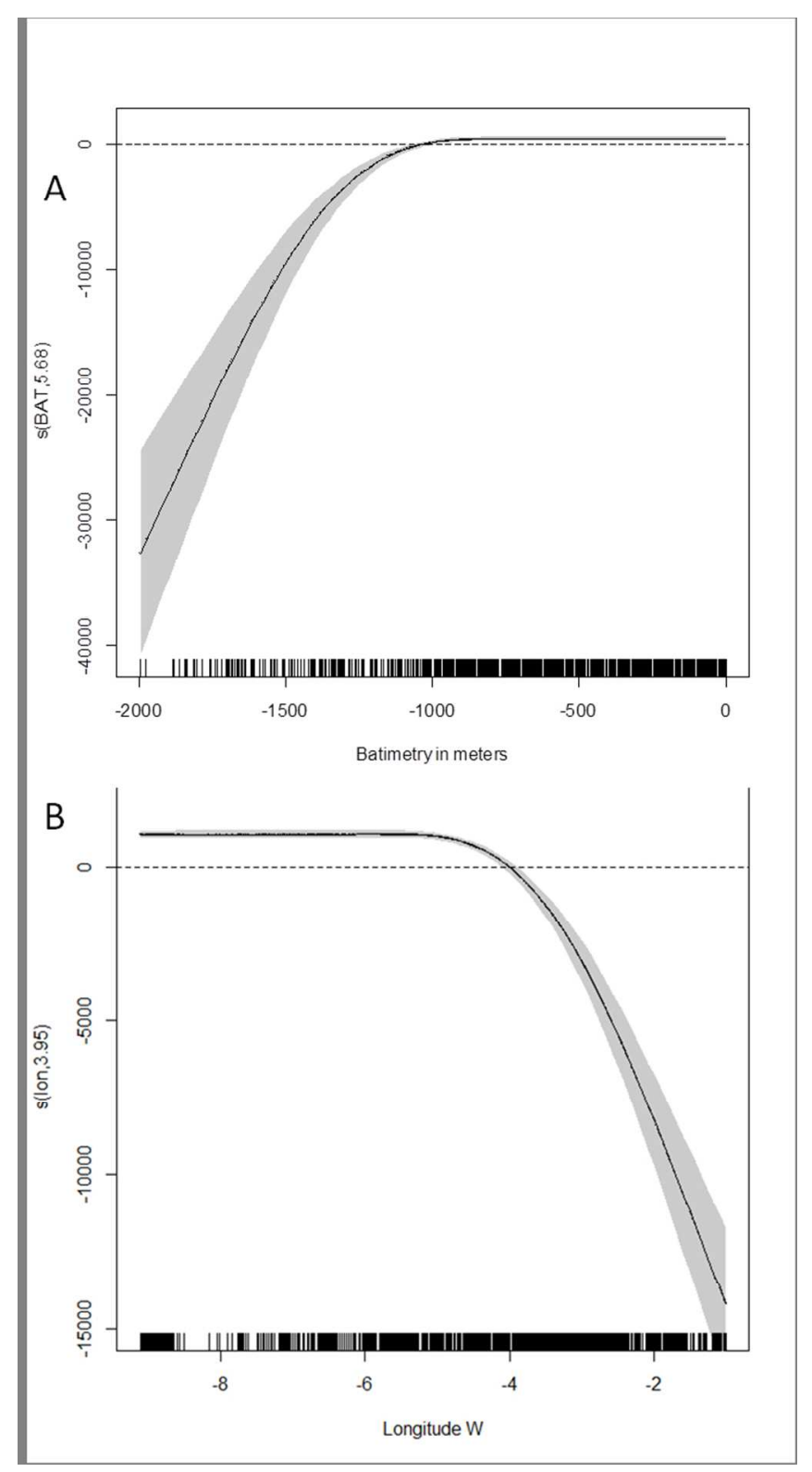

Fig.2. Smoothed functions for the selected predictive covariates in the model of probability of presence of killer whales in the study area in spring. Continuous line represents the point estimate and grey areas represent \pm 1 se. The small ticks on the $X$ axis represent the samples. (A) Bathymetry and (B) Longitude. 


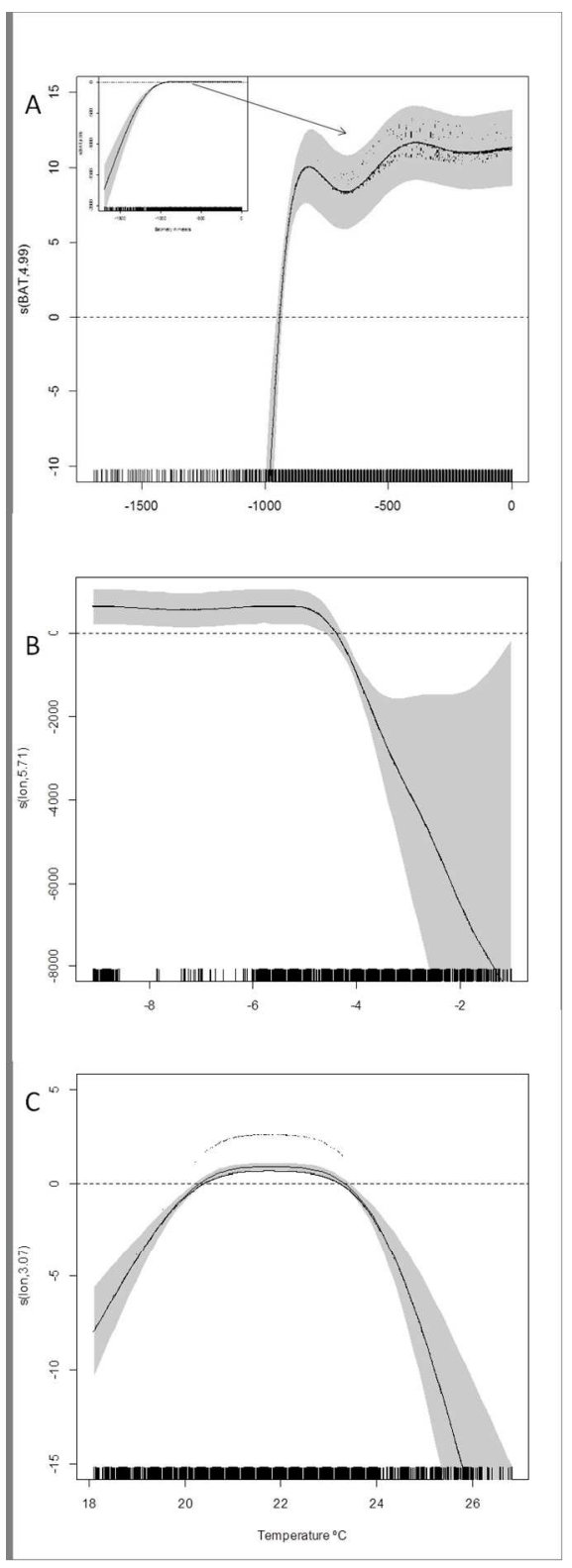

Fig. 3. Smoothed functions for the selected predictive covariates in the model of probability of presence of killer whales in the study area in summer. Continuous line represents the point estimate and grey areas represent \pm 1 se. The small ticks on the $X$ axis represent the samples. (A) Bathymetry; (B) Longitude and (C) Sea Surface Temperature. 


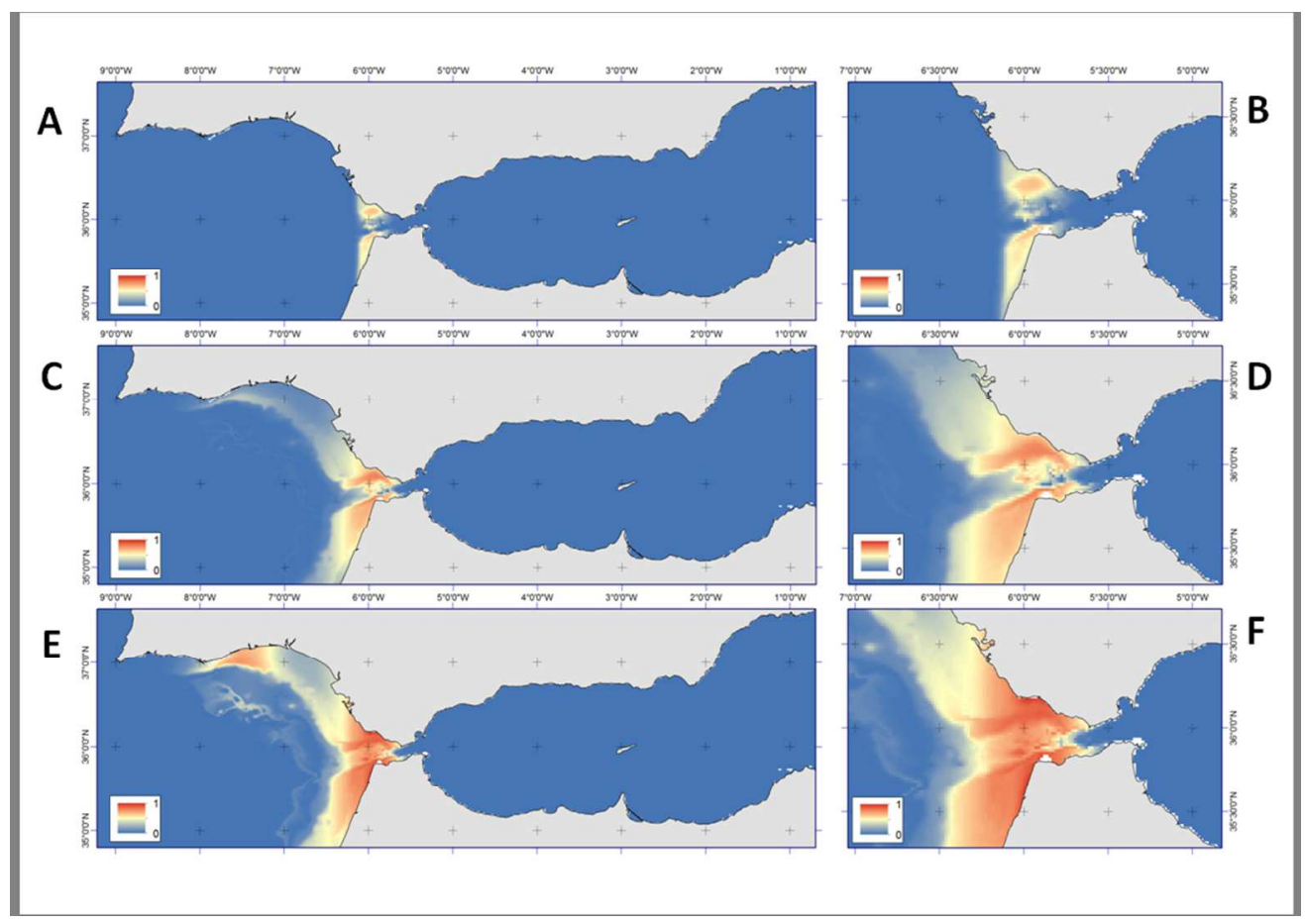

Fig. 4. Predicted density surface map of killer whales in the area from spatial modelling in spring by bootstraps. (A) the inferior $95 \%$ C.I. of the predicted model at southern Iberian Peninsula; (B) the inferior 95\% C.I. of the predicted model in the Strait of Gibraltar; (C) best predicted model at southern Iberian Peninsula, (D) best predicted model in the Strait of Gibraltar; (E) the superior 95\% C.I. of the predicted model at southern Iberian Peninsula and (F) the superior 95\% C.I. of the predicted model in the Strait of Gibraltar. 


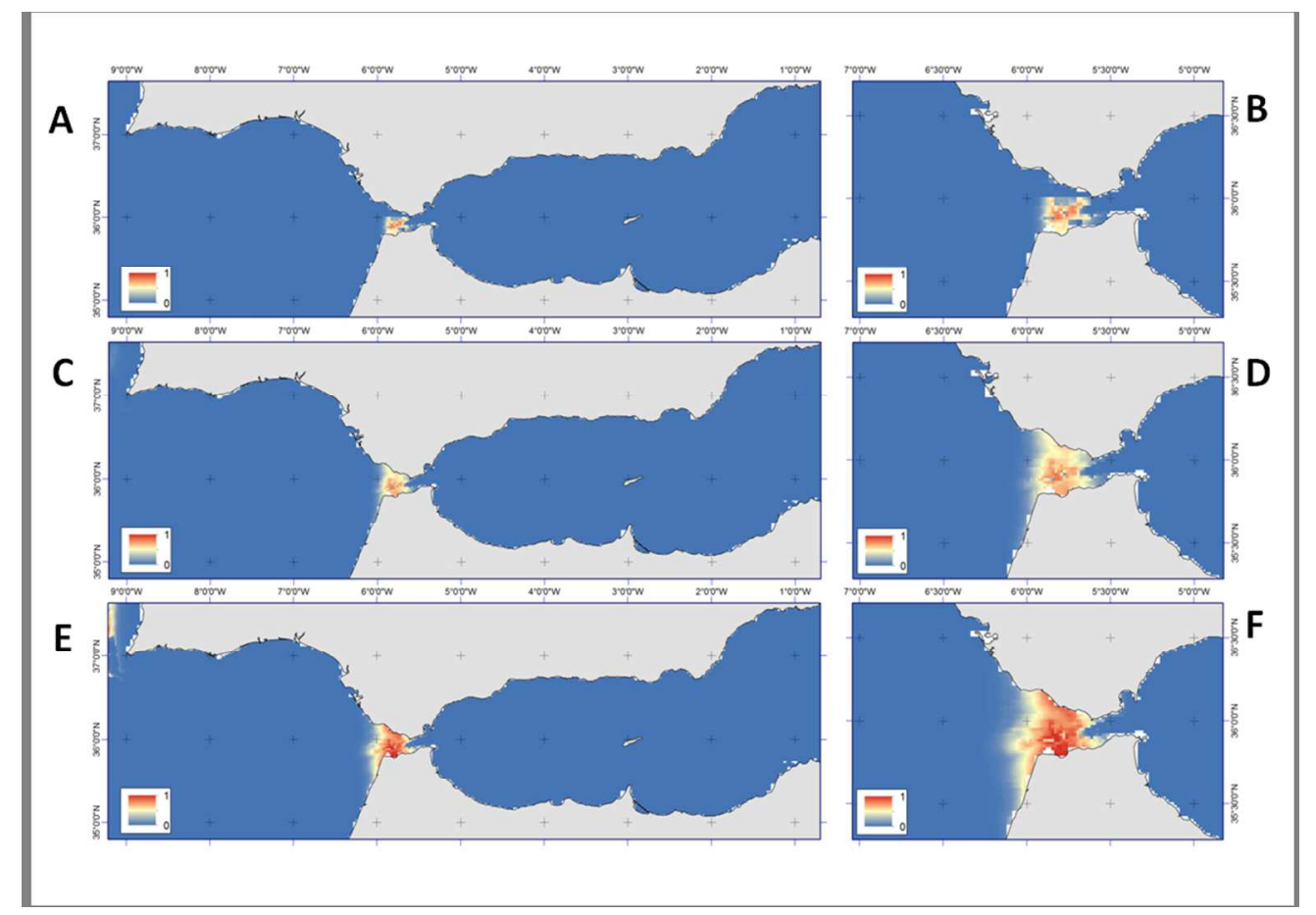

Fig. 5. Predicted density surface map of killer whales in the area from spatial modelling in summer by bootstraps. (A) the inferior $95 \%$ C.I. of the predicted model at southern Iberian Peninsula; (B) the inferior 95\% C.I. of the predicted model in the Strait of Gibraltar; (C) best predicted model at southern Iberian Peninsula, (D) best predicted model in the Strait of Gibraltar; (E) the superior 95\% C.I. of the predicted model at southern Iberian Peninsula and (F) the superior 95\% C.I. of the predicted model in the Strait of Gibraltar. 


\begin{tabular}{|c|c|c|c|c|c|}
\hline Covariates & GCV & $\Delta \mathrm{GCV}$ & AIC & $\Delta \mathrm{AIC}$ & $\begin{array}{c}\text { Dev } \\
\text { Explained }\end{array}$ \\
\hline $\mathrm{s}(\mathrm{BAT})+\mathrm{s}(\mathrm{lon})$ & 0.058853 & & 4102.552 & & $50.40 \%$ \\
\hline $\mathrm{s}(\mathrm{BAT})+\mathrm{s}($ lon $)+\mathrm{s}(\mathrm{ASPECT})$ & 0.061775 & 0.002922 & 4100.523 & -2.029 & $47.90 \%$ \\
\hline $\mathrm{s}($ lon $)+\mathrm{s}(\mathrm{ASPECT})$ & 0.064006 & 0.005153 & 4098.398 & -4.154 & $45.90 \%$ \\
\hline $\mathrm{s}($ lon $)$ & 0.064558 & 0.005705 & 4104.756 & 2.204 & $45.30 \%$ \\
\hline $\mathrm{s}(\mathrm{BAT})+\mathrm{s}(\mathrm{ASPECT})$ & 0.093139 & 0.034286 & 4117.656 & 15.104 & $21.50 \%$ \\
\hline $\mathrm{s}(\mathrm{BAT})$ & 0.094014 & 0.035161 & 4111.666 & 9.114 & $20.60 \%$ \\
\hline s(ASPECT) & 0.10867 & 0.049817 & 4123.602 & 21.05 & $8.42 \%$ \\
\hline
\end{tabular}




\begin{tabular}{cccrrr} 
Covariates & GCV & \multicolumn{1}{c}{ GGCV } & \multicolumn{1}{c}{ AIC } & \multicolumn{1}{c}{ AAIC } & \multicolumn{1}{c}{$\begin{array}{c}\text { Dev } \\
\text { Explained }\end{array}$} \\
\hline $\mathrm{s}(\mathrm{BAT})+\mathrm{s}($ lon $)+\mathrm{s}(\mathrm{SST})$ & 0.14259 & & 9384.136 & & $49.60 \%$ \\
$\mathrm{~s}(\mathrm{BAT})+\mathrm{s}($ lon $)$ & 0.14326 & 0.00067 & 9389.616 & 5.48 & $49.30 \%$ \\
$\mathrm{~s}($ lon $)$ & 0.17302 & 0.03043 & 9451.718 & 67.582 & $38.70 \%$ \\
$\mathrm{~s}(\mathrm{BAT})+\mathrm{s}(\mathrm{SST})$ & 0.18114 & 0.03855 & 9444.685 & 60.549 & $35.90 \%$ \\
$\mathrm{~s}(\mathrm{BAT})$ & 0.18902 & 0.04643 & 9459.7 & 75.564 & $33 \%$ \\
$\mathrm{~s}(\mathrm{SST})$ & 0.26926 & 0.12667 & 9567.393 & 183.257 & $4.69 \%$
\end{tabular}

